\title{
On the Impact of the Changes of Social Ideology and Institutions on Land Use in China since the 1950s
}

\author{
LU Qi, WU Peilin, WANG Guoxia, and ZHAN Jinyan \\ Institute of Geographical Sciences and Natural Resources Research, Chinese Academy of Sciences, \\ Chaoyang District, Beijing, 100101, P. R. China
}

\begin{abstract}
The impact of social and institutional changes on land resource use is an important component of the driving force of land use/cover changes. This paper primarily studies the characteristics and impacts of social and institutional changes on the use of land resources in China since the 1950s, which have played an important role in land use and land cover changes, but have not been studied enough by Chinese researchers in this field. Through discussion of the relation between social institution changes, changes of land resource management institutions and their impact on the changes of land resources, we identify and discuss the close connection between macro social ideology, institution and policy changes, and land use/cover changes in the context of China over the last 50 years, and establish the explanation and framework to illustrate the relationships and the phenomena.
\end{abstract}

Key words: land use, social ideological change, institutional change, China

\section{Introduction}

Compared with traditional China, modern China has witnessed profound changes in social ideologies, politics and institutions, management skills, rapid population growth, and economic development policies since the beginning of the 1950s. These social changes have influenced China in many aspects as human development, economic performance, and even natural environments. But, under the dominant thought of Chinese-Marxist philosophy and political economics from 1949 to 1978 , the only thing we could say was that social ideology was determined by objective realities, and the value of natural resources was not recognized as well. Logically, the relation between social ideology and institution and the objective realities is determined by objective realities, the impact of social ideology and institution on objective realities and the mutual interaction between the two sides had not been accepted, and the unconsciousness of land value and land use sustainability prevailed. If we said social ideology and institution change played an important role in the changes of social and natural realities, or if we advocated market-oriented land use, it was dangerous. Social ideology and institution changes in a society may greatly shape the society in many aspects as human development, economic performance, and landscape and natural environment by the theories of western philosophy, institutional economics, sociology, and environmentalism, which have been newly introduced to China since the open policy reform in 1978. It becomes more and more clear that different social ideology and institutions may determine different social and natural changes and that there is a structural connection between them. If the mutual interaction between social ideology and institutions and objective realities is fully understood, a society may more rationally build sound development strategies for that society, and it is particularly important for the sustainable development of the society. Land use changes, as one important component of the landscape or environmental changes, which are affected and shaped not only by natural factors but also by social ideology and institution changes, has been recognized by most western scholars in the field of land use/cover changes. For example, political structure, economic factors such as systems of exchange or ownership, and attitudes and values have been considered the 
most likely determinants of land use change (Tuner et al 1995). However, with the growth of Chinese LUCC studies in recent years, there are a lot of researchers focusing on the impact of various human activities on landscapes, GIS technology application, mapping, and so on, whereas, how these ideology and institution changes in politics and institutions have influenced and related to the land use/cover changes have not been studied enough by Chinese researchers. This fact shows that Chinese researchers are more or less constrained by Chinese-Marxist philosophy and political economics. So, for the full understanding of the mutual interaction between social ideology and institutional changes and land use changes in practice, it is important for Chinese scholars to launch researches on how social changes in ideology, politics and institutions have influenced and related to land use/cover changes. This paper mainly focuses on the discussion of the influences of social ideology and institutional change on land use changes in the context of China. Our purpose is to provide a case for deeper understanding of the driving forces of land use and cover changes in China.

\section{Social Ideological and Institutional Changes since the Beginning of the $1950 \mathrm{~s}$}

Under given social productivity, social progress generally depends on perfect and reasonable social ideology and institutions. When the Communist Party of China was in power more than 50 years ago, the re-modernization process in China was started. The purpose of the new social ideology and institutions was to build a modernized China, or as Mao Zedong once said in 1949, to turn an agricultural China into an industrial and strong China (Mao 1960). However, the social ideology and institutions had been established under the theories of communism or socialism combined with traditional Chinese ideologies, which were characterized by somewhat irrational and impatient mind and romantic ideals, so it was easy to have some political tragedies result from such social ideology and institutions, such as the Cultural Revolution, which seriously damaged the national economy and the modernization process of
China. But such social ideology and institutions were corrected and replaced by mixed social ideology and institutions, i.e. a combination of socialism and capitalism, or with some traditional ideologies, when the Party realized its mistakes and Chinese history entered into post-Mao era in 1978. Social ideology and institution changes in China since 1950s could be roughly divided into two periods, i.e. the first period from 1949 to 1978 and the second period from 1979 to the present day; 1978 could be viewed as the dividing line. Although the social ideology and the institutions are different in the two periods, the goal of making China a modernized country has remained the same.

The principal institutions influenced and changed by the social ideology changes during these two periods are ownership institution, management institution, law institution, and economic development strategy and policies. In the first period, the institutions of public and collective ownerships, planned economy and production, customs law system and bureaucratically social management with weak law and scientific supports were in the dominant position. In contrast to the characteristics of social institutions in the first period, these social institutions have been gradually replaced by ownership mixed among public ownership, collective ownership, and private ownership, market economy and production, modern law system, and service oriented social management with more or less strong law and scientific support in the second period. These institutional changes not only have greatly impacted the general social and economic development, but also influenced some specific institutions, management, and policy changes. The change of institutions and management and policies for land resources use is one of the examples, which has resulted from these institutional changes but has directly influenced the practical land use and cover changes. Therefore, the framework could be: general social ideology change drives social institution and management change and drives the specific institution and management changes and then the practical land use changes. 


\section{Land Use Institution, Policy and Management Changes}

Institution and policy changes for the use of China's land resources over the last 50 years could be summarized with the following three elements: 1) the gradual establishment of a legal system for land use and management; 2) the foundation of a unified and national organization for the management of land resources; and 3 ) the formation of a land resources market.

\section{Establishment of a legal system}

There have been two fundamental laws concerning the use of land resources, namely, the Land Reform Law of the People's Republic of China, issued in 1950, and the Land Management Law of the People's Republic of China issued in 1986. Beyond them, there are 29 corresponding laws, regulations, and official documents that have been issued in succession during these 50 years (Table 1).

The first law and those pre-prepared regulations as well as those to follow for land reform were in the nature of political changes in Chinese society (Zhao 1990; Zheng 2000). The major goals of the law focused on the confiscation of landlords' land, distribution of their land to individual farmers, management of some special land, and the set-up of executive organizations in charge of the land reform under the people's governments at different levels. Therefore, the purpose of this fundamental law was aimed at solving some pressing social problems of land ownership and land distribution facing China at that time, such as realizing farmers' private land ownership and "opening [the] way for the New China's industrialization." (The land reform law of the People's Republic of China 1950). It did provide the legal foundation for the successful land reform in practice and changed the land structure of traditional landlord ownership, and improved agricultural productivity. For example, because of the land reform, gross output of agriculture in China during the early years from 19491952 was increased by $48.47 \%$. A reasonable explanation for the increase is that the land reform gave great incentives to the farmers to input more labor in there newly gained land.
Some data show that total sown area in East China in 1952 increased $35.5 \%$ compared to that in 1949, unit labor input for some major products increased 5\% (maize), 25.7\% (cotton), $14.7 \%$ (wheat), $14.2 \%$ (corn) and $14.3 \%$ (rice) (Zheng 2000).

The traditional land use pattern was changed only within this limit. The newly established farmers' private land ownership was soon replaced by collective land ownership in rural and state land ownership in urban areas after 1953. At that time, China entered the long period of the planned economy system, industrialization, and rural collective movement, under which the special land management and land use patterns formed characteristics such as the disunity of national land management organization, no transfer rights of land, no perfect development of legal systems for land management, anti-urbanization bias with strict control on population migration, and so on.

The Land Management Law of the People's Republic of China is a more specific law for land use and management compared with the Land Reform Law of the People's Republic of China. It was issued under the different historical conditions of the changed social ideology, politics, and the national economic situation. When it was issued, the open and policy reform was conducted for six to seven years. Its principal purposes were: the reinstatement of the state and collective land use ownerships that were settled in the revised Constitution of the People's Republic of China in 1975, and the definition and permission of land use rights; the requirement of the governments at different levels to make overall land use planning; the protection of arable land; the regulation of construction land use; the supervision of various land use activities; and the penalty regulations for the illegal land use activities. The notable points of this law could be summarized as 1) the separation of land ownership. The significance of the regulations is to give individual farmers more freedom to use their arable land, which resulted in the diversification of land use or structural changes of land use; it also provided the opportunity to release the labor pressure on China's land resources, for example, some data show that in 1982 there were 6.57 million mi- 
Table 1. Major laws, regulations and official documents for land use in China since 1949

\begin{tabular}{|c|c|c|c|}
\hline \multicolumn{2}{|c|}{ Time } & \multicolumn{2}{|r|}{ Laws, Regulations and Official Documents } \\
\hline June 28 , & 1950 & Law & Land Reform Law \\
\hline Nov. 21, & 1950 & Regulation & Regulations of Land Reform in the Suburbs \\
\hline Dec. 5 , & 1953 & Regulation & Measures of Land Requisition for State Construction \\
\hline & 1954 & Law & Constitution \\
\hline Sept. 22 , & 1954 & $\begin{array}{l}\text { Official } \\
\text { Document }\end{array}$ & $\begin{array}{l}\text { Government Administrative Council: the Circular on Some Approval Jurisdic- } \\
\text { tion in 'Measures Change of State Land Requisition' }\end{array}$ \\
\hline Jan. 21, & 1956 & $\begin{array}{l}\text { Official } \\
\text { Document }\end{array}$ & $\begin{array}{l}\text { State Council: The Circular on Correction and Prevention of Waste Phenome- } \\
\text { non in the Land Requisition for State Construction }\end{array}$ \\
\hline Jan. 6, & 1958 & Regulation & Measures of Land Requisition for State Construction \\
\hline April, & 1962 & $\begin{array}{l}\text { Official } \\
\text { Document }\end{array}$ & $\begin{array}{l}\text { Comments of State Council's document transfer procedure on Ministry of } \\
\text { National Affair's Report on the Land Use Situation of Land Requisition for } \\
\text { State Construction in the Two Cities if Beijing and Tianjin }\end{array}$ \\
\hline October, & 1962 & $\begin{array}{l}\text { Official } \\
\text { Document }\end{array}$ & $\begin{array}{l}\text { State Council: Approval on the Questions in the Treatment of Requisitioned } \\
\text { Land in Guangxi }\end{array}$ \\
\hline & 1975 & Law & Constitution \\
\hline Mar. 5, & 1978 & Law & Constitution \\
\hline July 26 & 1980 & Regulation & Temporary Stipulations for the Construction Land Use of Joint Ventures \\
\hline May 14, & 1982 & Regulation & Regulations Rega \\
\hline Dec. 4 & 1982 & Law & Constitution \\
\hline June, & 1983 & $\begin{array}{l}\text { Official } \\
\text { Document }\end{array}$ & $\begin{array}{l}\text { State Planning Committee's Clarification on Regulation Regarding Land Requi- } \\
\text { sition for the State Construction }\end{array}$ \\
\hline Dec. 25 , & 1984 & $\begin{array}{l}\text { Official } \\
\text { Document }\end{array}$ & $\begin{array}{l}\text { State Planning Committee etc: Temporary Measures for Fixing Use of Requi- } \\
\text { sitioned Land Fee of Ministry of Agriculture, Husbandry and Fishery, etc; }\end{array}$ \\
\hline April 5, & 1985 & $\begin{array}{l}\text { Official } \\
\text { Document }\end{array}$ & $\begin{array}{l}\text { Temporary Management Measures of the Development and Construction Fund } \\
\text { Paid by Vegetable Land Requisition for State Construction }\end{array}$ \\
\hline July 25 & 1986 & Law & Land Management Law \\
\hline April 10, & 1987 & Regulation & Temporary Provisions Regardi \\
\hline Oct. 15, & 1987 & $\begin{array}{l}\text { Official } \\
\text { Document }\end{array}$ & Temporary Management Measures of Construction Land Use Plans \\
\hline Sept. 27, & 1988 & Regulation & Temporary Regulations Regarding Urban Land Use Tax \\
\hline May 19 & 1990 & Regulation & $\begin{array}{l}\text { Temporary Regulations Regarding the Sale and Transfer of Urban State Own- } \\
\text { ed Land Use Rights }\end{array}$ \\
\hline May 19 & 1990 & Regulation & $\begin{array}{l}\text { Temporary Management Measures for Stretch Land Developed and Run by } \\
\text { Foreign Investors }\end{array}$ \\
\hline Jan. 4 , & 1991 & Regulation & The Implementation of Provisions Regarding Land Management Law \\
\hline Jan. 25, & 1991 & Regulation & $\begin{array}{l}\text { Regulations Regarding Migrants' Compensation and Settlement Caused by } \\
\text { Requisition Land for Large-Middle Scale Project Construction of Water and } \\
\text { Electricity Facilities }\end{array}$ \\
\hline Mar. 22, & 1991 & Regulation & Management Regulations Regarding Urban House Removal \\
\hline July 5 & 1994 & Law & Management Law of Urban Real Estate \\
\hline Oct. 1 & 1997 & Law & Penalty Law \\
\hline Aug. 29, & 1998 & Law & Land Management Law (revised) \\
\hline Dec. 24 & 1998 & Regulation & Provisions Regarding Implementation of Land Management Law \\
\hline Oct. 22 , & 1999 & $\begin{array}{l}\text { Official } \\
\text { Document }\end{array}$ & $\begin{array}{l}\text { The Examination Measures of Construction Land Use Submitted by Ministry } \\
\text { of Land Resources to State Council for Approval }\end{array}$ \\
\hline
\end{tabular}

Source: Lin 2001. 
grants, but 121.07 million in 2002 (http://www. agri.gov.cn 2002), or 18.4 times in increase. 2) The definite regulation of overall land use planning, making this the first systematic regulation in Chinese law systems that attempted to establish systematic national land use planning based on regional land use planning at different administrative levels. It symbolizes a new era of rationalized and scientific land use in China. 3) The other contents of the law consisted of other land management laws such as construction of land use management, land use supervision, and penalties for illegal land use activities. These elements illustrate that the land use management in China has become more and more specific, decisive, and strict under somewhat western-oriented ideology and a marketoriented economic system in the open and policy reform period.

\section{The foundation of unified and national or- ganization for land management}

The State Bureau of Land Management was established in 1986, the same year that the Land Management Law of the People's Republic of China was issued. Afterwards, the provincial or other local land management bureaus were built up one by one, and finally the national land management system was formed. Besides the issue of Land Management Law, the establishment of the State Bureau of Land Management and the national land management system is another important event for the change in land use in China. Since the foundation of the People's Republic of China, there had been no such central and unified official organization under the State Council and its local system for land use management until 1986. Land resources usually were allocated at random by the central and local government departments that had a need to use land, so it provided an opportunity to gradually change the unregulated management of land use into a regulated, rational, and unified management system. And, with more and more obvious scarcity of land resources due to the rapid population growth and the development of industries in China, it was time for the central and local governments to strictly control and accurately manage China's land resources.

\section{The formation of a land resources market}

There were no land resource markets before the 1980s. Some explanations for the absence of the market are as follows: in the official ideology and economics or Marxism economics, land resources were not considered to be a valuable production factor; and private land ownership was forbidden. The government was afraid that the fluctuation of land rent might influence the prices of agricultural products and industrial products, therefore, land and its use rights were not allowed to be bought or sold during this long period. However, following the changes of the ruling social ideology, separation of land ownership and use rights in the legal system and land management institutions were established, and land resource markets were gradually formed. However, private land ownership was still not permitted. In 1987, the State Council issued the policy that the land use rights could be transferred with payment. In 1988, the People's Congress passed the revised draft of the Constitution, which deleted the prohibition provision of land lease, therefore, the content of land use rights transfer was added. In 1990, the land use rights of urban stateowned land were allowed to be rented or transferred according to the Temporary Regulations Regarding Land Use Rights Sale and Transfer of Urban State Owned Land. The deletion of the prohibition provision of land lease provided strong incentives for the active movement of land resources between owners and users and between users and other users. Now there are two classes of land markets in China, i.e. the first-class land market and the second-class land market.

The first-class land market mainly refers to the trade behaviors between different landowners and land users. The second-class land market mainly refers to the trade market between different land users. The trade forms include land transfer and land lease, though basically there are two sorts of land ownerships, i.e. state land ownership mainly practiced in urban areas, and collective land ownership mainly practiced in suburbs and rural areas. Regardless, it can be considered to be significant progress for China just to allow land use rights to be trans- 
ferred, because rational and scientific land use is mainly determined by how to use land, not who has the ownership of the land. The efficiency of the use of land resources has been much improved, and sellers of land use rights (they are mainly local governments at different levels, individual or ordinary farmers usually cannot easily transfer their land use rights due to their limited land resources) have the opportunity to gain benefits from transferring land use rights. According to some imperfect statistics, from 1978-1994, the whole county at least gained 241.9 billion Chinese yuan from the transfer of land use rights ( $\mathrm{Li}$ 1997).

\section{Impacts of Social Institution Changes on Land Resources Use}

For macro-understanding, we first provide a general picture of land use changes of the three major regions in recent years and possible changes in the future: North China, South China and Qinghai-Tibet Plateau (see the Fig- ure below). This macro division is roughly based on the basic physical division in China. This Figure is one of the results of the key project of China's ninth five-year plan (19962000 ), titled research of the agricultural resource perspective and its collocation optimization and rational distribution in China, which was completed in 2000 by the authors. It is based on the data of the project, the data of 1985 and 1990 is adopted from the general survey of national land use, the data of 1996 comes from the results of the national land resource investigation. The land use prediction for 2010 is based on the figures provided by each province's overall land use planning 1996-2010. Our purpose for making this map was to compare the general trends of land use changes from 1985 to 2010 between North China and South China from a macro point of view. From this map, we can see the following three major trends: 1) principal part of unused land is concentrated in North China, the reduction of unused land re-

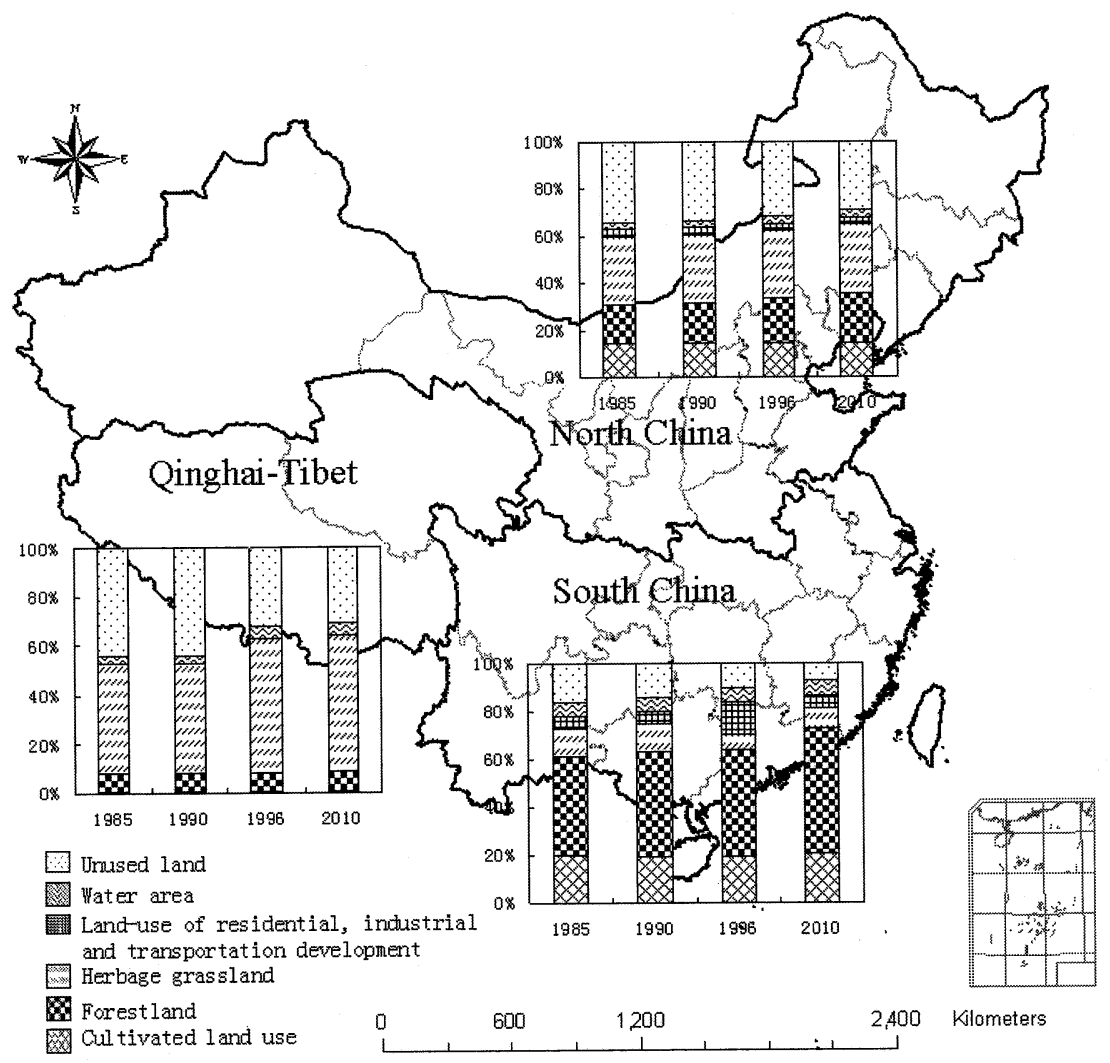

Figure 1. Land use changes in China by three major regions (1985-2010). 
source both in North China and South China is a long term trend, the reduction is particularly obvious in the south; 2) whereas the principal part of forest land is concentrated in South China, the increase of forest land is also a long term trend both for North China and South China; 3) besides slight increase, cultivated land keeps relatively stable. These facts reveal some significant changes in social ideologies and institutions. First, long term increase trend of forest land is consistent with the state development strategy raised in China's Agenda 21 issued by the central government and could be a significant symbol of the growth and awakening of ecological or environmental consciousness in the social ideologies and the corresponding institutions', it is an important change in China. Second, to feed China is a very important issue not only for China, but also for the world. It attracted international concern eight years ago (Brown 1995), therefore, occupation expansion of cultivated land has to be strictly prevented, keeping the cultivated land stable reflects the mixture of the traditional food selfsufficiency ideology, policies and the more strict management institutions of Chinese governments in the current situation of rapid industrialization and urbanization and social modernization. China is traditionally a highly politically centralized country, and it is easy for the main official ideologies and institutions to prevail all over China. It may be hard to identify or compare ideological and institutional impacts on land use changes in different regions, but may be comparatively easy to see the influences on land use changes in time series. Differences of regional land use changes may be mainly shaped by natural conditions in different regions.

The impacts of social institution changes on land resources use over these 50 years have varied; there have been both positive and negative results.

\section{Positive impacts}

Positive impacts are mainly: 1) the intensive land use rate has been improved; 2) the depth of change in the traditional land use structure; 3 ) the rapid increase of urban land use; 4) the growth of residential land use; 5) the gradual decline of land reclamation; and 6) the gradual formation of rational land use.

Improvement of intensive land use rate It could be seen that improvement of China's intensive land use rate took place after each major social institution change. For instance, the land redistribution at the end of the 1940s and the beginning of the 1950s increased the gross output of agriculture $48.47 \%$ due to the sharply increased labor input in arable land as we mentioned in the paragraph above. If we consider the low technology level at that time, the growth of agricultural output was mainly caused by the institutional change of land ownership, which gave tremendous incentives to farmers to increase their labor input and thus increased the intensive land use rate. Another example is the practice of the household responsibility system that was started throughout China at the end of the 1970s and the beginning of the 1980s. Since the Chinese farmers obtained their free land use rights, they were willing to enlarge their input of more factors such as labor, chemical fertilizers, or chemicals and some other modern input factors in land. For example, the yearly increase of chemical fertilizer input per Chinese mu was $0.36 \mathrm{~kg}$ from 1965 to 1978 , but $5.55 \mathrm{~kg}$ from 1978 to 1980 . This increase not only changed the intensive land use rate and the soil features, but also improved the agricultural output; the average gross output of agriculture per year was 3.7 billion yuan from 1949 to 1978 , but 26.3 billion yuan from 1978 to 1980 (State Statistical Bureau 1990). Today, China has basically solved its food supply problem. Since 1995, the total grain supply has exceeded total demand, and at present, China has a surplus of grain and other major agricultural products of about 8$9 \%$. This has provided an opportunity to adjust the mix of crops grown to make it more compatible with the market and relieve the longstanding tremendous pressures of grain production on agricultural resources and the ecosystem (Liu and Lu 2001).

\section{Change of traditional land use structure} We mentioned above that the Land Management Law of the People's Republic of China was issued under the different historical conditions of changed social ideology, politics, institutions, 
and the national economic situation. Compared with the Land Reform Law of the People's Republic of China, its focus was to make land use more effective and profitable. Accompanied by the gained progress of modern technology from the 1950 s to the 1970 s, and enough incentives by the new social ideology and institutions, especially the separation of land ownership and use rights, farmers had the opportunity to make more profits in changing their traditional agriculture structure and the corresponding land use structure. A study shows that the share of grain sown area accounted for $87.8 \%$ in the total sown area in 1952 , whereas, $78.9 \%$ in 1979 (Ma and Sun 1985), the annual average fall was $0.32 \%$, the decrease rate was very slow. But, the annual average decrease rate from 1978 to 1983 was $0.54 \%$. The agricultural structural adjustment was obviously accelerated. This sharp change reflects the impact of institutional change on land use structural change.

Rapid expansion of urban land use Urbanization is one important step in the modernization process. Rapid urbanization is also an important factor for the land use change in developing countries after World War II. It relates not only to the national macrodevelopment strategy change, but also to the land use institution and policy change. At the beginning of the 1950 s there were 160 major cities, the built-up area in total was $3,100 \mathrm{~km}^{2}$, $0.03 \%$ of China's total area, and 2,500 small towns. (The estimated average area is $0.4 \mathrm{~km}^{2}$ each, and the total was $1,000 \mathrm{~km}^{2}$.) Therefore, the total urban built-up area was $4,100 \mathrm{~km}^{2}$ at that time, or about $0.04 \%$ of the total area of China. In 1978 the built-up area was increased to $7,100 \mathrm{~km}^{2}, 0.07 \%$ of China's total area, the annual increase of the built-up area was about $107 \mathrm{~km}^{2}$, and the urban population increased $7.28 \%$ during the 28 years from 1949 to 1978 . From 1985 to 1990 , the number of cities in China had almost doubled, from 324 to 622 , and was 668 in 1998. The built-up area increased from $9,386 \mathrm{~km}^{2}, 0.09 \%$ of China's area to 17,940 $\mathrm{km}^{2}, 0.2 \%$ of China's total area, and the annual increase of the built-up area was $658 \mathrm{~km}^{2}$. If the built-up area of small towns is included, the total built-up area is about $34,000 \mathrm{~km}^{2}, 0.35 \%$ of the total land (Survey Team of Urban Society and Economy of National Bureau of Statistics 1999), plus the urban population increased $18.74 \%$ during the 22 years from 1979 to 2001 . Developing areas are quasi-urbanized areas, which appeared after the reform. According to the statistics provided by the state Management Bureau, China now has 2,804 various developing areas, the total land occupation is $7,620 \mathrm{~km}^{2}$, about $3 \mathrm{~km}^{2}$ each (1997 data), and, if the quasi-urbanized area is added to the total built-up area of $34,000 \mathrm{~km}^{2}$, the total built-up area in China is $41,600 \mathrm{~km}^{2}$, or about $0.43 \%$ of the territory, which is ten times the figure at the beginning of the 1950s.

Enlargement of residential land use "Poverty is not socialism," Deng Xiaoping once said in the 1980s. This phrase symbolizes a change in ideology. It means that the Party adopted the willingness for better living standards. After the policy reform, the government encouraged improvements in residents' living conditions, therefore a large scale residential building construction project was launched both in urban and rural China to compensate for the stagnant development during the planned economy period from 1953 to the end of the 1970s. According to the outline of National Land Use Planning, the allowed scale of the residential construction area in rural areas ought to be 13.7 million ha by 2000 , but the total area of residential land use in the rural towns and villages had reached 16.1 million ha in reality (1.7\% of China's area), exceeding 2.5 million ha by 1990 . One detailed investigation in a city of Jilin by the local land management institution showed that $95 \%$ of the households exceeded the residential building area. Residential construction in the city center has been oriented to the development of skyscrapers style. The residential districts in the surrounding areas of city center have been unceasingly developed in the recent years. Although it has been a very serious problem for rural households to exceed the planned residential building area, it lends proof to the fact that the residential construction expansion has been greatly developed.

Land reclamation change China is scarce in land resources compared with its population size, and arable land expansion depends on rec- 
lamation. However, most of the land reserves are concentrated in the remote areas as the north and the northwest of China. Land reserves in Xinjiang, Heilongjiang, Inner Mongolia, and Gansu account for more than $60 \%$, and more than $80 \%$ of the total land reserves are in the north. It is estimated that total land reserves amount to around 33.33 million ha, but only about 13.33 million ha are eligible to be reclaimed for farming. For food self-sufficiency and compensation of arable land reduction by non-agricultural uses, land reclamation has had to be concentrated in these remote and fragile regions. There has been a very close relationship between the growth of arable land and land reclamation in China. According to related data, China has opened about 3.27 million ha through reclamation since 1949 , but occupied around 3.13 million ha through various construction land uses in the last 50 years. Reclamation has played a very important role in the food supply of China, but it has also resulted in many environmental problems such as serious desertification, water and soil erosion, and so on. With more than 20 years of continuous growth in agricultural production, the present rich array of agricultural products can basically meet the demands of the huge population in China. In 1994, the Chinese government issued the China's Agenda 21, declaring sustainable development to be the basic state development strategy. At that time, agricultural growth by reclamation seemed to be neither environmentally nor economically sound. With the popularization of sustainable development throughout the world, the traditional pattern of reclamation will be gradually abandoned as economic and social factors continue to progress in China. The land reclamation rate will continue to decline, and land reclamation activities in remote and fragile areas will be replaced by the newly established development strategy of returning arable land to forest and grass ( $\mathrm{Lu}$, Zeng, and Zhan 2002).

Formation of rational land use Although there are still many problems in China's land use, under the modernized changes of the social ideology, politics, and institutions, the general tendency of its land use has been becoming more rational during these 50 years. The ra- tionalization of land use could be explained as follows: the land use changes mentioned above are favorable for the general goal of modernization from a historical point of view because the improvement of intensive land use has changed the traditional extensive land use model formed in the long historical period and increased greatly China's food supply ability. The readjustment of agricultural structure has helped increase the gross output of agriculture and the income of peasants through making land use more efficient, and at the same time provides rural laborers more job opportunities in nonagricultural industries. Rapid urbanization is an important step toward modernization, but it has also made spatial preparation for industrialization in the planned economy period and has provided urban areas for the huge number of migrants from rural areas to be urbanized in the market-oriented period. The enlargement of residential construction areas after the open and policy reform has greatly improved the residents' living conditions. Reclamation has been replaced by the national strategy of returning sloped arable land to forestland and grassland, because the Chinese government has been awakened in recent years to the dangers of large-scale reclamation, especially in the remote and fragile areas. The future of land use policies in China is being changed from development to protection. The new development strategy provides opportunities to improve the entire environmental conditions of China if it is kept for a long enough period.

\section{Negative impacts}

Negative impacts mainly include: 1) imperfect implementation of the relevant laws; 2) illegal land use activities; 3 ) loss of arable land to non-agricultural purposes; 4) desertification expansion; 5) water and soil erosion; and 6) land pollution.

Imperfect implementation of the relevant laws Laws are in place for better land management, but laws can be often avoided in China. Problems in land use mainly result from the imperfect implementation of the concerned laws and regulations. For example, land management organizations are relatively weak in the bureaucratic structure. They may have 
equal jurisdiction as other official organizations at the same level, but they are usually under the leadership of higher governments. Because they have to rely on the financial allocations from higher governments, when the higher governments plan to do something unfavorable for rational land use, land management organizations usually do not have an option to disagree. There are many evidences, for example, "Land Management Law" stipulates governments at different levels are responsible for making land use planning in their own administrative regions, but there are still 12 provinces (40\%), 73 prefectures (31\%), 765 counties (37\%), that have not completed their land use planning (Hou 1998). According to the investigations in Hubei, Anhui, and Jangsu, the ratio between real land use and planned land use is $4: 1$ or even $6: 1$. The investigation shows that there were 1080 construction projects, which ought to have the approval from the State Council for their land use, but only 202 projects applied, making up 18.7\% (Li 1997). For perfect use of land, the authority of land management organizations is needed. China traditionally is not a legal institutional society, but with the rapid establishment of legal system in the recent 20 years, the situation has considerably changed, but there is still a long way to go. This is particularly true for land management.

Illegal land use activities Illegal land use activities mainly result from some ambiguous concepts in 'Land Management Law,' and local leaders or governments can make use of these ambiguous regulations and have the right to rent or lease the land use rights of the collective land. For higher benefits, local leaders or governments are interested in the transfer of collective land, but the collective benefits could be easily damaged by corruption activities as well. For example, local governments illegally approve larger scale of land sale beyond their rights in a fragmented manner for extra benefits. The distribution of the income from the transfer of arable land between central government and local governments was definitely stipulated to be 5 to 5 in 1987, but, in fact, it was 3 to 7 in 1989 (Li 1997). After the reformation of the tax system in 1993, the arable land occupational tax has been set aside for the local governments, and remained in particular in counties of most provinces. Because illegal land use activities mainly resulted from local leaders and local governments, it is very difficult for the land management authorities to punish such illegal activities because the land management authorities are usually under the higher governments.

Over loss of arable land to non-agricultural purposes Competition for land in China is intense. Arable farmland is being lost to urbanization, industrialization, transportation systems, and recreational facilities. In most cases these uses are more profitable. Agriculture is becoming a relatively smaller proportion of the modern economy. Arable land continues to be lost to non-agricultural uses. The statistics of the occupation of arable land by nonagricultural constructions from 1985-1995 exceeded $20 \%$ of the planned figure; however, the occupation area is actually 2.5 times the statistics according to State Bureau of Land Management. Because of the State Bureau of Land Management, China has now 2804 various developing areas; the total land occupation is $7,620 \mathrm{~km}^{2}$, about $3 \mathrm{~km}^{2}$ for each; and most of them are built on the original arable land. The reduction of arable land is an inevitable consequence of rapid economic development. It is a common fact in China. Statistics show that in the past 50 years, the cultivated land in the Yangtze River Delta has been reducing at an average annual rate of $0.57-1.15 \%$. From 1989-1999, cultivated land was reduced averaging 16,000 ha annually in the Zhujiang River Delta. This was $65 \%$ of the total arable land reduction in the province. In the recent 15 years, the cultivated land has been reduced by 3,200 ha in Shenzhen, $89 \%$ of the total cultivated land area, 21,000 ha in Zhuhai (Chen 1996), $38 \%$ of the total cultivated land and 61,000 ha in Shanghai, or $20 \%$ of the total cultivated land. Arable land per capita in Wengzhou was 0.077 ha in 1949 , but 0.025 ha in 1995 , around $30 \%$ of that in 1949 (Hua 2001).

Desertification expansion Desertification expansion in China was averaging $1,560 \mathrm{~km}^{2}$ per year to $2,100 \mathrm{~km}^{2}$ during the 20 years from the 1950 s to the $1970 \mathrm{~s}$, but has reached 2,460 $\mathrm{km}^{2}$ per year since the 1980s (Shen 2001). Rec- 
lamation or over-reclamation by hasty methods is the major contributor to the serious desertification in China, which may contribute $80 \%$ of the rate. The annual loss caused by desertification is estimated at about 54 billion yuan. Land desertification is threatening 100 countries, or 3.6 billion ha of land annually. Desertification has plagued China for a long time, particularly in the last 100 years. By estimate, about $120,000 \mathrm{~km}^{2}$ of land became desert in historical times and another $50,000 \mathrm{~km}^{2}$ in the past 100 years. The total area of desertified and potentially easy to be desertified land in China is about 0.84 million $\mathrm{km}^{2}, 2.2$ million $\mathrm{km}^{2}$, which is about 8.7 and $23.4 \%$ of the territory of China respectively. Deserts are 1.53 million $\mathrm{km}^{2}$, about $15.9 \%$ of the territory of China (Wu et al. 1994; Lu, Zeng, and Zhan 2002). Factors contributing to the desertification expansion are various: dry or semi dry climate conditions, rapid population growth and under-developed productivity, but also irrational human activities such as over-rapid population growth, overuse grassland and non-protection management in the fragile regions, play the decisive role. Some data show that the contribution rate in the desertification expansion is $94.5 \%$ in north China (Qu and Li 1992), these irrational human activities reflect the ideologies of traditional birth view, ecologically unconsciousness of environments and non-or-weak protection management institutions.

Water and soil erosion Factors of ideologies and institutions contributing to water and soil erosion are similar to desertification. Due to agricultural activities and land reclamation in mountainous areas in the dry and semi dry regions, water and soil erosion have become more serious. According to some data sources, the area of soil and water erosion has been increased from 1.16 million $\mathrm{km}^{2}$ at the beginning of $1950 \mathrm{~s}$ to 1.8 million $\mathrm{km}^{2}$ in $1990 \mathrm{~s}$. With very serious water and soil erosion, particularly in the reclamation areas, countless nutrients in the soil have been removed, greatly weakening the carrying capacity of land in China and may threaten the future of agricultural and economic development. For instance, soil organic content is relatively low, about $1-2 \%$ in general in China. In the Sanjiang Plain, soil organic contents have decreased from $6-11 \%$ at the beginning of the 1950 s to $3-5 \%$ in recent years. In general, the soil resources of China have been deteriorating. The quality of both need to be preserved and the reclaimed land is a decisive factor for the land productivity. The area subject to water loss and soil erosion in the 1990s was twice as much as in the 1970s. The total area of the Loess Plateau is $484,000 \mathrm{~km}^{2}$, about $278,000 \mathrm{~km}^{2}$ of the plateau has been heavily eroded, accounting for $57 \%$, and about 110,000 $\mathrm{km}^{2}$ in its northern semiarid areas are badly eroded, accounting for $23 \%$. Although the soil erosion areas have been reduced to $25 \%$, new water loss and soil erosion areas have appeared due to stone quarries, mining, and reclamation of land on slopes (Liu and Lu 1999). By estimate of remote sensing report issued by the State Council, the annual loss of surface soil is about 5 billion tons, accounting for $19.2 \%$ of the world. The Changjiang River contributes 2.4 billion tons and the Yellow River contributes another 1.6 billion tons; it costs about 30 billion yuan in losses per year (Shen 2001).

Land pollution Arable land has been reduced sharply and the soil is deteriorating. For more benefits, the overuse of fertilizer is so popular that China has some of the highest fertilizer application rates in the world, and well above those of most intensive production systems in developed countries, $30-50 \%$ of nitrogen fertilizer applied is lost to the environment. Poor macronutrient balance contributes to poor efficiency. The consequences are many: higher production costs and lower net incomes for farmers, air pollution from fertilizer factories, eutrophication of water bodies, reduction in drinking water quality, increasing number of red tides, and excessive nitrate levels in vegetables. The irrational land use has resulted in an imbalance in soil nutrition. Nitrogenous fertilizer has been over-applied; phosphate fertilizer has been accumulated in the soil; the application of potash fertilizer is inadequate. And the development of the livestock sector (especially pork production) over the past $20-30$ years has been faster than the crop sector, and its share in the total GDP of agriculture has been doubled. Per capita consumption has more or less doubled over the past 20 years, although rural con- 
Table 2. Basic framework of the relation between social institution change and land use change in China

\begin{tabular}{|c|c|c|}
\hline Goal & \multicolumn{2}{|c|}{ Social goal of modernization } \\
\hline Stages & Stage I (1949-1978) & Stage II (1979-present) \\
\hline Ideologies & $\begin{array}{l}\text { Communism or socialism; } \\
\text { Determinism philosophy; } \\
\text { Marxism political economics; } \\
\text { Unconsciousness of land value; } \\
\text { Unconsciousness of land use } \\
\text { sustainability }\end{array}$ & $\begin{array}{l}\text { Quasi-socialism or quasi-capitalism; } \\
\text { Pluralism philosophy; } \\
\text { Western economics; } \\
\text { Consciousness of land value; } \\
\text { Formation of land use sustainability } \\
\text { consciousness }\end{array}$ \\
\hline $\begin{array}{l}\text { Institutions \& social } \\
\text { development strategy }\end{array}$ & $\begin{array}{l}\text { Highly central planned economy; } \\
\text { State and collective ownership; } \\
\text { State and collective production systems; } \\
\text { Industrial bias strategy \& food } \\
\text { self-sufficiency }\end{array}$ & $\begin{array}{l}\text { Socialist market economy; } \\
\text { State, collective, private and other } \\
\text { ownerships; } \\
\text { State, collective, private and other } \\
\text { production systems; } \\
\text { Development strategy of world market } \\
\text { and resources oriented }\end{array}$ \\
\hline Land management & $\begin{array}{l}\text { Disunity of national land management } \\
\text { organization; } \\
\text { No transfer rights of land; } \\
\text { No legal systems of land management }\end{array}$ & $\begin{array}{l}\text { United and national land management } \\
\text { organization; } \\
\text { Transfer rights of land; } \\
\text { Formation of land management legal } \\
\text { systems }\end{array}$ \\
\hline Land use structure & $\begin{array}{l}\text { Simple land use structure; } \\
\text { Anti-urbanization under the strict } \\
\text { control on population migration; } \\
\text { Extensive land use pattern }\end{array}$ & $\begin{array}{l}\text { Diversified land use structure; } \\
\text { Rapid urbanization and large scale } \\
\text { population migration; } \\
\text { Intensive land use pattern }\end{array}$ \\
\hline Consequences & $\begin{array}{l}\text { Low efficiency of land resources use; } \\
\text { Land degradation by serious water and } \\
\text { soil erosion }\end{array}$ & $\begin{array}{l}\text { High efficiency of land resources use; } \\
\text { Land degradation by chemical pollution; } \\
\text { Serious corruption in land use } \\
\text { management }\end{array}$ \\
\hline
\end{tabular}

sumption levels tend to be $25-50 \%$ lower than that in urban areas. However, the economic benefits have carried severe environmental penalties. The environmental costs have been high with large volumes of solid wastes from pig and poultry units; $40 \%$ or more of wastes being discharged without treatment into watercourses; and increasing emissions of nitrous oxide and ammonia to the atmosphere. Moreover, the relative importance of this pollution is likely to grow worse in the future, if point source industrial and domestic wastes are not brought more under control.

\section{The Basic Framework of the Relation between Social Institution Change and Land Use Change in China}

Based on the above discussions on the facts of the changes of social ideology and institution, land use management institutions, and practices in the last 50 years in China, we established the basic framework below. This framework clearly shows that different social ideology and institution background could drive different land use practice and different consequences, though the general goal of Chinese society in the last 50 years was to realize modernization. It not only reveals the corresponding relationship between social institution changes and land use changes in the different modernization stages, demonstrating the necessity for more liberation of the ruling social ideology and the relevant institutional reform of land use management in China for much better or rational land use practice, but also provides the basic framework for the more specific and quantitative studies on the relationship between social institution changes and land use 
changes in future, because China is in the new historical period of modernization and sustainable development.

\section{Conclusion}

Generally speaking, China is traditionally not a legally institutional society. However, under the re-modernization development in the last 50 years, the situation has changed a great deal because of the changes of the ruling social ideology and institutions, the establishment of a legal system, and the rationally-oriented management structure established within the past 20 years. But, there is still a long way to go, particularly in the area of land management.

Our study on the facts in China provides the case showing that institutional changes in a society can shape not only the society in human development, economic performances, but also the natural environment. Land use change, as one important component of the environmental changes, is affected and shaped by social ideology and institution changes directly and indirectly, but it is more basic and fundamental, especially in the context of Chinese culture.

Land use practice and changes in China in the re-modernization of these 50 years, especially in the recent 20 years, shows that the institution and policy changes for land use management determined by the general trend of the social ideology and institution changes have gradually played a positive role in constraining and correcting irrational land use practice, and in environmental improvement and protection, though there still remain many problems for further solution in future.

Because we have found the important role of these ideological and institutional changes in the land use changes from the historical experiences and consider social ideology and institution as one of the important driving forces for land use and land cover changes, we may conclude that there is still room for further reform in order to achieve more rational land use management and practice.

(Received 26 May 2003) (Accepted 31 July 2004)

\section{References}

Brown, R. 1995. Who will feed China. New York: W. W. Norton \& Company (Li Y. ed.), 1997. Existence and development. Beijing: China Great Land Press. (C)

Chen, L. 1996. Land use trend in the Pearl River Delta. Acta Scietiarum Universitatis Sunvatseni 35, Suppl.: 70-76. (CE)

Hou, D. M. 1998. Problems in land use planning and management system in China. Chinese Rural Economy 3: 31-36. (CE)

Hua, W. 2001. Land use change in Wenzhou. Soil 2: 81-85. (CE)

Lin, Z. J. ed. 2001. Comparative study on land laws in the Mainland China, Hong Kong, Macao, and Taiwan. Tianjin: Tianjin University Press. (C)

Liu, J., and Lu, Q. eds. 1999. Land use and sustainable development in Loess Plateau, Northwest China. Beijing: China Environmental Science Press. (C)

Liu, J., and Lu, Q. eds. 2001. Management of land and water resources in coastal China. Beijing: China Environmental Science Press. (C)

Lu, Q., and Ren Guo Z. eds. 2002. Perspective of agricultural resources, the rational allocation of agricultural resources and the distribution of agricultural production. Beijing: Science Press. (C)

Lu, Q., Zeng, L., and Zhan, J. 2002. Land reclamation in China from the early 1950s to the late 1990s. In Land-use changes in comparative perspective, ed Himiyama, Y., Hwang, M., and Ichinose, T., pp. 177-187. Science Publishers, Inc.

Ma, H., and Sun, S. eds. 1985. A study on economic structure of China. Beijing: China People's Press. (C)

Mao, Z. ed. 1960. Selection of Mao Zedong VI. Beijing: China People's Press. (C)

Qu, G. P., and Li, J. C. 1992. Population and environment in China. Beijing: China Environmental Science Press. (C)

Shen, G. F. ed. 2001.Construction of ecological environment and water resources use and protection in China. Beijing: China Hydro-Power Press. (C)

State Statistical Bureau Network. Sept. 11, 2002. http://www.agri.gov.cn. (C)

State Statistical Bureau. 1990. Collection of historical statistics (1949-1989). Beijing: China Statistical Press. (C)

Survey Team of Urban Society and Economy of National Bureau of Statistics eds. 1999. Cities China 1949-1998. Beijing: Xinhua Press. (C)

The Committee of People's Central Government, 1950. The land reform law of the People's Republic of China. Beijing: China People's Press. (C)

Tuner II, B. L., Skole, D., Sanderson, S., Fischer, G., Fresco, L., and Leemans, R. eds. 1995. IGBP report No. 35 and HDP report No. 7, Land-use and landcover change-science/research plan report, pp. 1824. Stockholm and Geneva. 
Wu Chuan J., and Guo Huan C. eds. 1994. Land use in China. Beijing: Science Press. (C)

Zhao, X. M. ed. 1990. The history of land reform in China 1921-1949. Beijing: China People's Press. (C)
Zheng, Y. ed. 2000. A study on the land reform of China. Beijing: China Agricultural Press. (C)

(C): written in Chinese

(CE): written in Chinese with English abstract 